\title{
Genetic and environmental factors affecting some reproductive traits of Holstein cows in Cuba
}

\author{
A Menendez Buxadera ${ }^{1}$, L Dempfle ${ }^{2}$ \\ 1 Centro de Investigación para el Mejoramiento Animal, Carretera Central Km 21 1/2, \\ Cotorro, Havana, Cuba; \\ 2 International Trypanotolerance Center, PMB 14, Banjul, Gambia
}

(Received 6 March 1996; accepted 14 August 1997)

\begin{abstract}
Summary - A total of 226651 fertility records of dairy cows obtained from 1980 to 1988 was studied in order to determine the environmental and genetic factors affecting the reproductive performance of Holstein cows under Cuban conditions. Only $43.9 \%$ of the inseminated females were pregnant at first service; however, for heifers this value was $63.1 \%$. The seasonal variability was higher for heifers and for primiparous than for older lactating cows. The best performance was found from February to April, whereas during the hot and humid summer (July to September) poorer results were obtained. Age at calving or number of calvings was another important environmental source of variation: the earlier the calving the poorer is the next reproductive performance. The genetic analyses were made within calving number with the REML procedure. For heifers (226 sires, 45575 records) the heritability and the genetic coefficient of variation were: 2.26 and $10.94 \%, 3.24$ and $11.24 \%$, and 3.04 and $6.19 \%$ for conception rate (CR), numbers of services per conception ( $\mathrm{SG}$ ) and conception status (CS $=1 / \mathrm{SG}$ ), respectively. For first calving females (280 sires, 43647 records) the results were: 1.94 and $15.93 \%, 3.25$ and $12.80 \%$, and 3.47 and $9.47 \%$ for CR, SG and CS, respectively. For the second and third calving, the results were poorer. For the calving interval and days open, the heritabilities were between 1.86 and $4.64 \%$. The results of SG were selected as the best and more useful traits showing high genetic correlations $(>0.60)$ for the same traits in different calving number.
\end{abstract}

Holstein cattle breed / reproduction traits / genetic parameters / tropical conditions

Résumé - Facteurs génétiques et environnementaux intervenant sur les performances de reproduction des vaches Holstein à Cuba. Au total 226651 enregistrements de fertilité de vaches laitières obtenus de 1980 à 1988 sont analysés en vue de déterminer les

Correspondence and reprints: F Ménissier, Station de génétique quantitative et appliquée, Inra, 78352 Jouy-en-Josas cedex, France 
facteurs génétiques et environnementaux intervenant sur les performances de reproduction de vaches Holstein dans les conditions cubaines. Seulement 43,9\% des femelles inséminées sont gestantes à la première insémination, alors que pour les génisses ce taux est de $63,1 \%$. La variabilité due à la saison apparaît plus élevée chez les génisses et primipares que chez les vaches plus âgées. Les meilleurs résultats sont obtenus de février à avril, alors que les plus mauvais sont observés durant l'été (juillet à septembre), qui est chaud et humide dans les conditions cubaines. L'âge au vêlage et le rang de vêlage sont aussi d'importantes sources environnementales de variation. Plus le vêlage est précoce, plus la reproduction suivante est mauvaise. Les analyses génétiques ont été réalisées intrarang de vêlage en utilisant une méthode REML. Pour les génisses (226 pères, 45575 performances), les héritabilités et coefficients de variation génétiques sont de 2,26 et 10,94\%, de 3,24 et $11,24 \%$ et de 3,04 et 6,19\% respectivement pour le taux de conception (CR), le nombre d'inséminations par fécondation ( $S G)$ et l'état de gestation $(C S=1 / S G)$. Pour les primipares (280 pères, 43647 performances), ces résultats sont de 1,94 et 15,93\%, de 3,25 et $12,80 \%$ et de 3,47 et 9,47\% respectivement pour CR, SG et CS. Pour les vaches au deuxième et troisième velages, les estimations sont plutôt inférieures. L'intervalle entre vêlages et la durée entre vêlage et fécondation ont des héritabilités estimées variant entre 1,86 et 4,64\%. Les résultats relatifs au nombre d'inséminations par gestation (SG) conduisent à considérer ce critère comme le meilleur et le plus efficace pour la sélection, manifestant par ailleurs une forte corrélation génétique $(>0,60)$ entre rang de vêlage pour ce critère.

race bovine Holstein / performances de reproduction / paramètres génétiques / conditions tropicales génétiques

\section{INTRODUCTION}

Milk production is the main cattle goal in Cuba. Great amounts of resources have been used, not only in construction of cattle barns and infrastructure, but also thousands of Holstein females have been imported from Canada. A national breeding plan (NBP) was established in 1964, in which artificial insemination (AI) played an important role in crossbreeding between native Zebu cattle and Holstein sires. The general strategy and some results of NBP are offered in Anonymous (1978) and Prada (1984).

The population of purebred Holstein cows is relatively large (more than 100000 heads) and it is very important to analyze the general performance of all traits of economic importance in order to improve the national breeding scheme. For milk production and its constituents, an analysis was made by De los Reyes (1985) for several environmental factors. The main genetic parameters were reported by Guerra et al (1987), whereas some aspects on genotypic $\times$ environmental interaction and its role in the estimation of sire breeding value were presented by Menéndez Buxadera and Guerra (1981) and Menéndez Buxadera et al (1989).

According to the results previously mentioned, it could be concluded, regardless of the stressing environmental factors affecting dairy traits, that a very important genetic variability exists; therefore a breeding scheme in the Holstein population could be carried out. In this sense, it will be very useful to determine the characteristics of reproductive performance of the Holstein breed in Cuba since this is the most important individual factor affecting cattle production in this country. 
For the last 15 years, a great number of papers has been published with respect to genetic aspects of reproductive performance of dairy cattle (Janson, 1980; Hansen et al 1983; Jansen, 1986; Weller 1989). In general terms, there is a consensus that a large number of traits related to reproduction shows low heritability (lower than $10 \%$ ), but a high genetic variability. Considering this fact and also the economic importance of fertility, certain traits of reproductive performance should be considered in the selection criterion (secondary traits) for a breeding scheme.

Unfortunately, under tropical conditions almost no research related to this topic has been conducted. For this reason, a study of the genetic and environmental aspects of reproductive performance of Holstein cattle in Cuba was carried out and the main results will be presented in this paper.

\section{MATERIALS AND METHODS}

\section{Available data}

A total of 270000 individual records of Holstein cows calving from January 1980 to December 1988 throughout the country was available for this study. These data sets belong to a system developed at the National Center for Cattle Recording (CENCOP) to maintain the control of the Holstein as a pure breed but also some important reproductive data have been collected:

date of pregnancy and calving;

registration number of the cows and sire of the calf;

number of insemination services in which the cow was pregnant;

herd code;

results of calving:

abortion - if gestation period was less than 260 days;

stillbirth or not - if gestation period was between 260 and 295 days;

sex of the calf - no abortion.

Taking into account the data available, a procedure was conducted in which the permanent file of identification of each animal maintained at CENCOP was merged with the reproductive file mentioned previously in order to obtain the registration number of the sire of the cow and birth date of the cow.

As a consequence of this process, the new data set has a total of 232291 records with the information of each cow.

The number of calvings was not available in the original file, so it was decided to generate according to age at calving. Table I shows the general characteristics of the definitive data set.

Only Holstein sires born in Cuba and with a minimum of 20 daughters in a specific calving and distributed in at least five herds were considered for genetic studies; however the exact figures will be presented in the respective tables. 
Table I. Characteristics of data sets available on reproductive performance of Holstein cows in Cuba.

\begin{tabular}{lccc}
\hline $\begin{array}{l}\text { Age at } \\
\text { calving }^{\text {a }}\end{array}$ & $\begin{array}{c}\text { Number of } \\
\text { calvings }\end{array}$ & $\begin{array}{c}\text { Number of } \\
\text { records }\end{array}$ & $\begin{array}{c}\text { Number of } \\
\text { sires of cows }\end{array}$ \\
\hline $24-36$ & $0-1$ & 52879 & 453 \\
$37-51$ & 2 & 61331 & 421 \\
$52-66$ & 3 & 44023 & 410 \\
$67-83$ & 4 & 29262 & 400 \\
$>84$ & 5 & 39156 & 395 \\
Total & & 226651 & \\
\hline
\end{tabular}

a Age in months. In the case of calving 1 the reproductive performance in heifers was known.

\section{Traits}

The following reproductive traits were studied:

number of services per pregnancy

conception status

rate of conception for first services

calving interval (in days),

$$
\begin{aligned}
\mathrm{SG}_{i} ; & \\
\mathrm{CS}_{i} & =100 \cdot\left(1 / \mathrm{SG}_{i}\right) ; \\
\mathrm{CR}_{i}= & (100 \text { to pregnant at first } \\
& \text { service, } 0 \text { otherwise }) ;
\end{aligned}
$$

$\mathrm{CI}_{i}(i$ : number of calving); interval between calving and pregnancy (in days) $\mathrm{DO}_{i}$ ( $i$ : number of calving).

Records ending with an abortion, as well as records outside of the range 300-730 days for CI and 20-450 days for DO were deleted. The first three $\mathrm{CI}_{i}$ and $\mathrm{DO}_{i}$ were analyzed. With the logical exception of $\mathrm{DO}_{i}$ and $\mathrm{Ci}_{i}$, all reproductive traits are determined for any value of $i$ (between 0 and 4).

\section{Management systems}

The organization of cattle production in Cuba is mainly based on large state enterprises (more than 10000 heads), which are fairly uniform with respect to structure and organization. The dairy units have around 200 females which are milked twice daily with milking machines. From 10 am to $4 \mathrm{pm}$, all cows are kept indoors where they receive forage or silage and water, and graze the rest of the time. Inseminations are conducted early in the morning or late at night and the service bulls are selected yearly according to a plan for each enterprise. As a rule, between two and five service bulls are used at the same time in each herd. Pregnancy diagnosis is made by rectal palpation (after 60-90 days of insemination, by a specific technician). All the individual records of each animal are maintained at the unit, and once a month an official inspector from CENCOP visits the herd in order to estimate milk yield of each cow in each milking. All data are sent to CENCOP once a month.

\section{Statistical procedures}

Two different statistical analyses were performed. The first model was as follows:

$$
Y_{i j k l}=\mu+H_{i}+M_{j}+A_{k}+e_{i j k l}
$$


where $\mu$ is the general mean; $H_{i}$ is a fixed effect of a combination of herd and year which was absorbed; $M_{j}$ is a fixed effect of month of calving (or month of pregnancy) for $j=1, . .12 ; A_{k}$ is a fixed effect of number of calvings (or age at pregnancy) for $k=1, . .4 ; e_{i j k l}$ is a random residual.

This model was applied in order to determine the magnitude of the fixed effects of certain environmental factors affecting each dependent variable. Age at calving was considered to be a factor. Solutions for age and months were estimated after constraining the last level of each factor to zero.

The estimation of genetic parameters was the objective of the second mixed model which has the following matrix notation:

$$
\mathbf{Y}=\mathbf{X} \boldsymbol{\beta}+\mathbf{Z s}+\mathbf{e}
$$

where: $\mathbf{Y}$ is a vector of observations; $\boldsymbol{\beta}$ is a vector of fixed effects including age and herd-year-season of calving (natural trimester); $\mathbf{s}$ is as vector of random sire effects and $\mathbf{e}$ is a vector of random residuals, and $\mathbf{X}$ and $\mathbf{Z}$ are incidence matrices.

The following assumptions were made:

$$
\begin{array}{ll}
E(s)=\mathbf{0} & \operatorname{Var}(s)=\mathbf{I} \sigma_{\mathbf{s}}^{2} \\
E(e)=\mathbf{0} & \operatorname{Var}(e)=\mathbf{I} \sigma_{\mathbf{e}}^{2} \\
E(y)=\mathbf{X} \boldsymbol{\beta} & \operatorname{Var}(y)=\mathbf{Z Z} \mathbf{Z}^{\prime} \sigma_{\mathbf{s}}^{2}+\mathbf{I} \sigma_{\mathbf{e}}^{2}
\end{array}
$$

The $\sigma_{\mathbf{s}}^{2}$ and $\sigma_{\mathbf{e}}^{2}$ were estimated by restricted maximum likelihood (REML) (Patterson and Thompson, 1971). The general statistical properties and description of this method of variance components are well illustrated by Kennedy (1981), Dempfle et al (1983) and Lin and McAllister (1984). The variance components estimated for $\mathrm{SG}_{i}$ were used for breeding value estimation (EBV) through the BLUP procedure with a mixed model similar to model 2 , but with the age at calving as a covariable. The computer program was developed by Caleyo (1989) and was applied within calving number. The relationship matrix was not considered.

The genetic correlation $(\mathrm{Rg})$ between $\mathrm{SG}_{i}$ was estimated by two methods. The first procedure was published by Calo et al (1973) and was very well presented by Blanchard et al (1983) and is based on the weighted covariance between estimated $\mathrm{EBV}_{i}$; in that case, only those sires with more than 70 effective daughters on each calving were considered. The second estimation of Rg was based in a REML procedure with a model similar to model 2 but using the expected components of the variance of a new trait $\mathrm{SG}_{T}=\left(\mathrm{SG}_{i}+\mathrm{SG}_{i+1}\right)$. In order to fulfill these conditions, a new data set was formed with those cows with records on $\mathrm{SG}_{i}$ in adjacent calvings.

\section{RESULTS}

The distribution of data for number of services per conception for different calvings is shown in table II. Only $43.86 \%$ of the females were pregnant at first service (this result is equivalent to conception rate to first insemination) and gives clear evidence of the low reproductive performance of Holstein cattle under Cuban conditions. The results for heifers are quite acceptable; however, for lactating females, a dramatic breakdown is observed in fertility rate. 
Table II. Frequency distribution for number of services per conception in the first four calvings of Cuban Holstein cows.

\begin{tabular}{|c|c|c|c|c|c|c|c|}
\hline \multirow{2}{*}{$\begin{array}{l}\text { Number of } \\
\text { inseminations } \\
\text { per conception }\end{array}$} & \multirow{2}{*}{$\begin{array}{c}\text { Number } \\
\text { of } \\
\text { data }\end{array}$} & \multirow{2}{*}{$\begin{array}{l}\text { Overall } \\
\text { frequency } \\
(\%)\end{array}$} & & \multicolumn{4}{|c|}{ Frequency (\%) within calving } \\
\hline & & & 0 & 1 & 2 & 3 & $\geqslant 4$ \\
\hline 1 & 99418 & 43.86 & 63.05 & 41.37 & 37.44 & 37.03 & 35.77 \\
\hline 2 & 54143 & 23.89 & 21.37 & 24.26 & 24.46 & 25.34 & 25.42 \\
\hline 3 & 29911 & 13.20 & 8.61 & 13.60 & 14.90 & 15.07 & 15.67 \\
\hline 4 & 17357 & 7.66 & 3.94 & 8.14 & 9.11 & 9.09 & 9.12 \\
\hline 5 & 10541 & 4.65 & 1.75 & 5.28 & 5.67 & 5.31 & 5.59 \\
\hline 6 & 6332 & 2.79 & 0.74 & 3.19 & 3.45 & 3.24 & 3.50 \\
\hline 7 & 3879 & 1.71 & 0.34 & 2.00 & 2.12 & 1.90 & 2.20 \\
\hline 8 & 2338 & 0.98 & 0.11 & 1.04 & 1.33 & 1.27 & 1.31 \\
\hline 9 & 2832 & 1.25 & 0.09 & 1.12 & 1.52 & 1.75 & 2.02 \\
\hline Total & 226651 & 100 & 52879 & 61331 & 44023 & 29262 & 39156 \\
\hline
\end{tabular}

\section{Environmental effects}

The results of the statistical analysis according to model 1 show very highly significant effects $(P<0.001)$ for the different factors included; however, the determination coefficient $\left(R^{2}\right)$ of the model was between 9.2 and $12.4 \%$ for all traits evaluated in heifers and first calving stages. For older animals (more than two calvings) the $R^{2}$ was between 3.6 and $26.9 \%$. In all cases, the highest $R^{2}$ was obtained for $\mathrm{SG}_{i}$ and the lowest for $\mathrm{CR}_{i}$.

The solutions for month effects on heifer, first, second and third calving conception status $\left(\mathrm{CS}_{i}\right)$ are shown in figure 1 . Although only $\mathrm{CS}_{i}$ is presented, the general pattern was the same for the rest of the characters. The best results were obtained in March and April (lower $\mathrm{SG}_{i}$, and higher $\mathrm{CR}_{i}$ and $\mathrm{CS}_{i}$ ), whereas the poorest fertility rate was in September and October. Plotting climatological data on the same figure shows the very evident relationship between the hot and humid summer and a lower reproductive performance, and the relationship between the winter and the less humid period from January to April and the best results for $\mathrm{CS}_{i}, \mathrm{CR}_{i}$ and $\mathrm{SG}_{i}$.

Concerning days open $\left(\mathrm{DO}_{i}\right)$ and calving interval $\left(\mathrm{CI}_{i}\right)$, month effects were the same as for $\mathrm{CS}_{i}, \mathrm{CR}_{i}$ and $\mathrm{SG}_{i}$, which was as expected. However, the most important component of $\mathrm{DO}_{i}$ and $\mathrm{CI}_{i}$ is the interval between calvings and first service and these characters were not available in our data sets, so no more details can be provided on these traits.

The year effect was highly significant $(P<0.001)$ for the main traits studied. The solutions for each character expressed as deviations from the last year are shown in table III. In general terms, during the period of time represented in our data sets, a positive trend in reproductive performance of our Holstein females was found; however, even with these changes an optimum or near optimum level of fertility is never reached. The analysis of the effect of years was made also within calving number and the same pattern was found except in heifers, which showed an opposite trend during the period. 


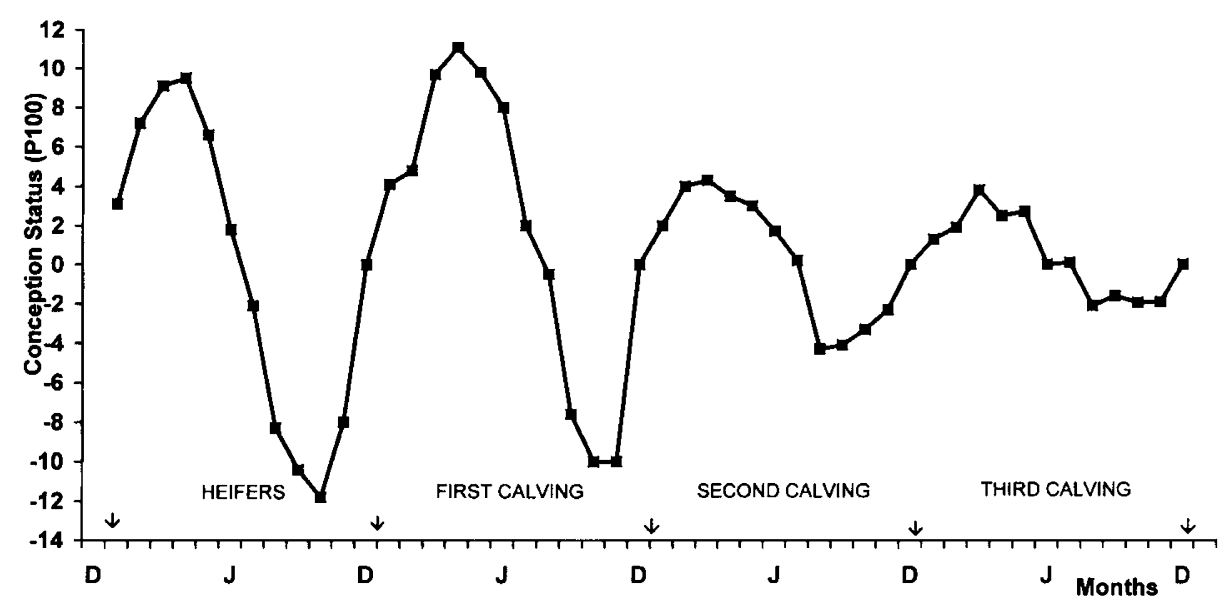

\begin{tabular}{lcccc}
\hline Categories of females & Heifers & First calving & Second calving & Third calving \\
\hline Conception rate (1st service) & 63.1 & 41.5 & 37.5 & 37.3 \\
No of service by pregnancy & 1.65 & 2.41 & 2.56 & 2.54 \\
Conception status (\%) & 78.1 & 62.3 & 59.3 & 59.4 \\
\hline
\end{tabular}

Fig 1. Solutions for months for conception status (\%) for differents categories of female Holstein cows in Cuba.

Table III. Solutions for year effects on different reproductive traits ${ }^{\mathrm{a}}$.

\begin{tabular}{lcrrrrr}
\hline \multirow{2}{*}{ Year } & $\begin{array}{c}\text { Number of } \\
\text { observations }\end{array}$ & \multicolumn{5}{c}{ Traits } \\
\cline { 3 - 7 } & & $C S$ & $C R$ & $S G$ & $D O$ & $C I$ \\
\hline 1980 & 12178 & -7.0 & -8.7 & 0.45 & 62 & 63 \\
1981 & 14807 & -5.2 & -5.2 & 0.42 & 51 & 51 \\
1982 & 17221 & -4.9 & -6.9 & 0.25 & 40 & 40 \\
1983 & 22771 & -3.2 & -3.2 & 0.1 & 62 & 63 \\
1984 & 25960 & -4.2 & -5.4 & 0.24 & 33 & 33 \\
1985 & 35299 & 1.1 & 1.0 & -0.09 & 32 & 33 \\
1986 & 30127 & -2.4 & -3.7 & 0.12 & 41 & 41 \\
1987 & 30196 & -4.6 & -6.9 & 0.15 & 0 & 0 \\
1988 & 33212 & 0 & 0 & 0 & & \\
General mean & & 64.2 & 44.1 & 2.32 & 150 & 434 \\
\hline
\end{tabular}

a The symbols for each trait and units of expression are: SG, number of services for pregnancy; DO, interval from calving to next pregnancy, (days); CS, conception status (\%); CI, calving interval, (days); CR, conception rate for first service, (\%). ${ }^{\mathrm{b}}$ The numbers for CI and DO were lower $(29 \%)$ in these two traits. For obvious reasons, there are no data for 1988. 
The effect of age or number of calving on the dependent variables was highly significant $(P<0.001)$. This was expected according to the information offered in table II. In general, the reproductive performance decreases as the number of calving increases as a consequence of cumulative stress due to lactation and previous reproductive disorders. When data were analyzed within calving number, the trend of age effects was negative, so the younger the calving is reached the poorer is the next reproductive performance of lactating females.

\section{Genetic effects}

The results of the mixed model show a highly significant effect $(P<0.001)$ of sires for all traits. The heritability $\left(h^{2}\right)$ for each character and variance component estimated by REML are presented in table IV, where the additive genetic coefficient of variation $(\mathrm{CVg})$ is included.

For $\mathrm{CR}_{i}$ and $\mathrm{CS}_{i}$, the genetic variance was more or less the same for different calvings, with the exception of second calving in which an unexpected result was found. For $\mathrm{DO}_{i}$ and $\mathrm{CI}_{i}$, an opposite pattern was found and a clear reduction in the genetic variance was obtained for older cows compared to primiparous cows. The genetic variance for $\mathrm{SG}_{i}$ increased 2.8 times for first calving with respect to results in heifers; however, for second and third calving the estimates were lower. The total phenotypic variance increases when estimating in heifers to third calving. As a consequence of these particular trends in both variance components, the $h^{2}$ for all traits was higher for heifers and first calving. The same results were obtained for CVg.

Concerning the number of reproductive characters available it would be necessary to perform a certain type of discrimination. In this context, it will be very important to take into account not only the value of $h^{2}$ and $\mathrm{CVg}$, but other peculiarities, such as facilities for recording and multiple objectives in the principal factors limiting the level of productivity of populations. In this sense, it will be very useful to conduct a relative comparison among some fertility parameters in different populations of Holstein cows (table V). Before 100 days after calving there is not a clear difference among the populations of percentage of females inseminated, which is very important to consider because the climatological conditions, systems of management and level of feeding are quite different in the three countries. The real problems emerge when we look at the percentage of pregnant females before 100 days after calving. According to this complete relative comparison and taking into account the results of Caral et al (1984), who reported that only $43 \%$ of cows not pregnant at first service presented second heat in a normal period of time, it can be concluded that at least in female Holstein populations, limiting factors are closely related to the number of services per conception $\left(\mathrm{SG}_{i}\right)$. Together with this advantage, this character is related to first service conception rate, is easy to record under field conditions in heifers and lactating cows and, furthermore, it will be useful for other purposes such as sire fertility evaluation; thus, $\mathrm{SG}_{i}$ will be the preferred trait in our breeding objectives. However, it is necessary to determine the relationship between $\mathrm{SG}_{i}$ in different types of females. 
Table IV. Variance components, heritability $\left(h^{2}, \%\right)$ and genetic coefficient of variation $(\mathrm{CVg}, \%)$ for some reproductive traits in Cuban Holstein cows.

\begin{tabular}{|c|c|c|c|c|c|c|}
\hline \multirow[t]{2}{*}{ Characters $^{\mathrm{a}}$} & \multirow{2}{*}{$\begin{array}{c}\text { Calving } \\
\text { number }^{\mathrm{b}}\end{array}$} & \multicolumn{2}{|c|}{ Variance } & \multirow[t]{2}{*}{$\mathrm{h}^{2}$} & \multirow[t]{2}{*}{$C V g \%$} & \multirow{2}{*}{$\begin{array}{c}\text { Number of } \\
\text { observations }\end{array}$} \\
\hline & & Genetic & Total & & & \\
\hline \multirow[t]{4}{*}{$\mathrm{CR}$} & 0 & 47.8504 & 2117.3410 & 2.26 & 10.94 & 286 \\
\hline & 1 & 42.6093 & 2196.9775 & 1.94 & 15.93 & 280 \\
\hline & 2 & 10.9601 & 2223.2959 & 0.49 & 11.09 & 226 \\
\hline & 3 & 49.9943 & 2263.8460 & 2.21 & 17.58 & 165 \\
\hline \multirow[t]{4}{*}{ SG } & 0 & 0.03424 & 1.05729 & 3.24 & 11.24 & 45575 \\
\hline & 1 & 0.09500 & 2.92332 & 3.25 & 12.80 & 43647 \\
\hline & 2 & 0.04913 & 3.08983 & 1.59 & 10.21 & 31497 \\
\hline & 3 & 0.07023 & 2.56712 & 2.74 & 11.16 & 20615 \\
\hline \multirow[t]{4}{*}{ CS } & 0 & 23.2960 & 767.0071 & 3.04 & 6.19 & \\
\hline & 1 & 34.6743 & 999.2592 & 3.47 & 9.47 & \\
\hline & 2 & 22.1467 & 1030.0785 & 2.15 & 8.06 & \\
\hline & 3 & 27.3545 & 998.3392 & 2.74 & 9.02 & \\
\hline \multirow[t]{3}{*}{ DO } & 1 & 324.1464 & 8833.7458 & 3.67 & 12.09 & 257 \\
\hline & 2 & 170.5853 & 7078.2313 & 2.41 & 10.19 & 236 \\
\hline & 3 & 257.8096 & 11239.9497 & 2.29 & 10.37 & 177 \\
\hline \multirow[t]{3}{*}{ CI } & 1 & 326.7983 & 6961.8021 & 4.64 & 4.26 & 24814 \\
\hline & 2 & 207.6600 & 8981.4814 & 2.31 & 3.34 & 21285 \\
\hline & 3 & 187.1134 & 10060.9302 & 1.86 & 3.18 & 14725 \\
\hline
\end{tabular}

a The symbols for each trait and units of expression are: SG, number of services for pregnancy; DO, interval from calving to next pregnancy, (days); CS, conception status, (\%); CI, calving interval (days); CR, conception rate for first service, (\%); CVg, (genetic standard deviation/mean of the trait) $* 100{ }^{\text {b }}$ It is referred to heifers, first, second and third calvings, respectively. ${ }^{c}$ The number of sires in each line of CR; on the line of SG, number of data. The same meaning for the numbers presented for DO and CI.

Table V. Percentage of Holstein cows inseminated and pregnant before 100 day after calving in three populations.

\begin{tabular}{lcccl}
\hline Country & $\begin{array}{c}\text { Number } \\
\text { of data }\end{array}$ & \multicolumn{2}{c}{ Percentage of cows: } & \multicolumn{1}{c}{ Author } \\
& & Inseminated & Pregnant & \\
\hline Cuba & 29476 & 76 & 37 & Menendez Buxadera $\left(1987^{*}\right)$ \\
Holland & 79987 & 78 & 73 & De Kruif (1975) \\
United States & 19633 & 80 & 78 & Foote (1978) \\
\hline
\end{tabular}

* Unpublished data.

The general pattern of this study (table VI) shows that there are medium to high genetic associations between $\mathrm{SG}_{i}$ at different calvings. The results were poorer with non-consecutive records in comparison to adjacent ones. The Rg estimated by the covariance of $\mathrm{EBV}_{i}$ was higher than the results of REML; however, the differences would not suggest that the same genetic bases exist for this trait measured at different stages of the reproductive life of the cows. 
Table VI. Genetic correlations ${ }^{\text {ab }}$ between number of services for conception $\left(\mathrm{SG}_{i}\right)$ in different calvings.

\begin{tabular}{lcccccc}
\hline & \multicolumn{2}{c}{$S G_{1}$} & \multicolumn{2}{c}{$S G_{2}$} & \multicolumn{2}{c}{$S G_{3}$} \\
\hline $\mathrm{SG}_{0}$ & $\mathbf{0 . 6 2 2}$ & $(137)$ & $\mathbf{0 . 3 9 0}$ & $(107)$ & $\mathbf{0 . 4 7 6}$ & $(79)$ \\
& $\mathbf{0 . 5 9 0}$ & $(108)$ & $\mathbf{0 . 4 6 1}$ & $(86)$ & $\mathbf{0 . 5 3 4}$ & $(61)$ \\
& $\mathbf{0 . 4 9 9}$ & & - & & - & \\
$\mathrm{SG}_{1}$ & & & $\mathbf{0 . 8 8 3}$ & $(128)$ & $\mathbf{0 . 2 8 7}$ & $(94)$ \\
& & & $\mathbf{0 . 8 8 7}$ & $(101)$ & $\mathbf{0 . 3 6 1}$ & $(75)$ \\
$\mathrm{SG}_{2}$ & & & $\mathbf{0 . 6 4 3}$ & & - & \\
& & & & & $\mathbf{0 . 9 3 3}$ & $(100)$ \\
& & & & & $\mathbf{0 . 9 4 0}$ & $(78)$ \\
\hline
\end{tabular}

a The results on the first two lines are the genetic correlations estimated on estimated breeding value of the sires (the same as model 2 but with age as a covariable); between brackets is the number of sires. The first line is with a minimum of 70 daughters per sire and the second line is with a minimum of 100 daughters per sires. ${ }^{b}$ The third line on the diagonal is the genetic correlation estimated by REML (model 2).

\section{DISCUSSION}

Unfortunately, there are not many references available on reproductive performance of Holstein cattle in the tropics. However, it is obvious from our results that the level is very low (see table II). According to Roman Ponce (1992) this is the general trend in tropical conditions and this low fertility rate of cattle represents the principal limiting factor affecting the productivity of cattle in these regions.

The seasonal variation obtained in these results is similar to those patterns reported in the subtropical regions of Mexico and Florida (Ingraham et al, 1974; Thatcher et al, 1984) and in the very hot and arid environmental conditions of Arizona (Monty, 1984) and Israel (Heimann, 1982; Ron et al, 1984). Many studies have been conducted in order to study the role of heat stress in the summer on the productive and reproductive performances of cattle in that area, with the objective of reducing the depressive effects with a new management system. According to Thatcher (1974), Thatcher et al (1984), Monty (1984) and Wazdauskas et al (1986), the maximum temperature after insemination is one of the main factors affecting the reproductive performance of Bos taurus cattle in tropical countries. High temperature causes a complete hormonal imbalance, which in turn may change the flow of nutrients to the uterus, and at the same time raises the uterus temperature. This mechanism contributes to creating a more hostile 'uterus environment' and increases the probability of fertility failure or subsequent embryo death. In figure 1 it can be observed that the magnitude of the month effect is very intense for all cattle categories; however, it would be evident that this environmental stress was twice as high for heifers and first calving females as for the rest of the cows. In fact, this behavior is contradictory in the literature (Thatcher, 1974; Thatcher et al, 1984), according to which the older lactating females must be more variable and more sensitive to heat stress. It is possible to speculate on this apparent paradox. When an adequate level of feeding and management is available, the live weight at first calving of a medium Holstein female is $500 \mathrm{~kg}$, ie, $80 \%$ of the adult weight. Under 
such conditions, the variability of fertility traits in heifers and first calving females can be less affected by heat stress; however, this is very far from our conditions. The developement and body weight curves of Holstein females in Cuba are poorer than those expected for this breed (Menéndez Buxadera et al, 1983); on average our females reach approximately $400 \mathrm{~kg}$ live weight in the middle of first calving, which means that this type of animal is less mature (in the sense of weight). Therefore, a higher percentage of the nutrients received must be used for the growing process. This mechanism could account for the higher variability and sensitivity of younger females under our conditions.

All these environmental factors require a more detailed and profound research in order to determine the physiological mechanism. However, the practical consequences of the seasonal variation in reproductive performance of Holstein females under our tropical conditions could be used. For instance, these results show that from September to January around $60 \%$ of the cows (not heifers) calving in that period corresponded to the season of higher fertility rate (see fig 1). According to this pattern, it would be highly recommended to inseminate the majority of the females from January to April with semen of Holstein sires of higher breeding value for milk production (principal traits in our breeding scheme). The preliminary estimates of such a policy show an improvement of not less than $20 \%$ in genetic potential in our female population with respect to the normal practice of bulls in service all year round.

According to our results it was clear that the $h^{2}$ for different fertility traits were low $(<5 \%)$ and similar to many reports on this subject (see review of Menéndez Buxadera, 1993); however, the genetic variability (table IV) was higher than most of the results in the literature (see Janson, 1980; Berger et al, 1981; Raheja et al, 1989 for SG and Baptist and Gravert, 1973; Janson, 1980; Jansen, 1986 for nonreturn rate as a trait related to $\mathrm{CR}$ ). This is due to the reduced culling rate applied in our female population, so these data show a complete picture of the real genetic variability in the reproductive performance of Holstein cattle under the tropical conditions of Cuba. The potential of this variability has not been considered by many researchers on account of the low $h^{2}$ value. According to Maijala (1987) this is a pessimistic point of view regarding the possibilities of genetic improvement for fertility traits.

For $\mathrm{DO}_{i}$ and $\mathrm{CI}_{i}$ there was a clear reducing $h^{2}$ pattern when the number of calving increased. In fact, this trend is contrary to the results published by Berger et al (1981), Hansen et al (1983), Jansen (1986) and Strandberg and Danell (1988) who obtained a small increase in $h^{2}$ and $\mathrm{CVg}$ in older females. For the rest of the traits it was evident that these genetic parameters were higher in the first two stages (heifer and first calving), which is in correspondence to Van Raden et al (1987), Raheja et al (1989) and Weller (1989). The results for the second calving were quite low and no clear explanation was found.

As a matter of fact, the general pattern for higher variability in younger females in comparison to multiparous cows could be a very important advantage in our breeding scheme, since the EBV for characters of the reproductive complex must be determined as early as possible, and higher genetic variability is equivalent to major possibilities for selection and breeding. This is true only if the traits evaluated in heifers and first calving females were in close relationship with the same characters in older cows. 
The information available on that subject is contradictory. European reports (Janson, 1980; Distl, 1982; Jansen, 1986) showed that the same reproductive characters in both types of females present the same genetic base so the results of heifers and primiparous cows can be used for sire evaluations. Another recommendation was made by North American researchers (Hansen et al, 1983; Raheja et al, 1989; Van Raden et al, 1989) who reported lower genetic correlations $(R g<0.30)$ although the tendency was the same.

According to our results (table VI) the genetic correlation $(\mathrm{Rg})$ for $\mathrm{SG}_{i}$ in different calvings was higher than 0.60 when $\mathrm{Rg}$ was estimated by the weighted covariance between EBV of the sire, whereas $\mathrm{Rg}>0.49$ when the REML procedure was used. Both estimates are difficult to compare because the value of Rg depends on the quality of the data set. However, great differences were not observed. Our point of view is in favor of the results obtained through the $\mathrm{EBV}_{i}$ of the sire, because in REML the same design matrix was used and the computing requirement was greater.

According to our results it is possible to conclude that the same genetic bases exist between certain fertility traits measured in different stages of the reproductive life of cows. This aspect will be very important for sire evaluation purposes since the records of heifers and first calving could be used in this sense.

\section{CONCLUSIONS}

This study shows positive yearly trends in the level of reproductive performance of Holstein cattle under Cuban conditions, nevertheless, the general mean was quite low. Calving number and month of calving were the principal environmental factors affecting the fertility rate of Holstein females; this aspect was more critical in heifers and primiparous in comparison to older lactating cows. According to these results the best performance was achieved from February to April, corresponding to the winter season, while during the hot and humid summer (July to September) very poor results were obtained. This seasonal pattern must be interpreted as a general reproductive behavior of Holstein cattle in the tropics, which could be used under practical conditions.

From a breeding point of view, our study confirms that the $h^{2}$ of the characters corresponding to the reproductive complex shows the expected low value $\left(h^{2}<5 \%\right)$. However, the genetic coefficient of variation was higher than the value reported for developed and temperate countries (see Menendez Buxadera, 1993), so plenty of space is available for breeding. The number of services per conception $\left(\mathrm{SG}_{i}\right)$ was selected as the character more related to our limiting factor affecting the reproductive performance of this breed under tropical conditions. Furthermore, $\mathrm{SG}_{i}$ could be used for various purposes and it will be possible to measure this at an early age (heifers). In this sense, the relationship between $\mathrm{SG}_{i}$ in heifers and first calving females was 0.60 and higher than the 0.88 found between older cows, which allows us to use all information available for breeding value estimation of AI sires. Taking into account that the procedures used for Rg estimation could be affected by some bias, it is highly recommended to use a more powerful statistical procedure such as an individual multitrait animal model, with different matrix design, although the computing demand will be higher. 


\section{ACKNOWLEDGMENT}

The authors wish to express their gratitude to their colleague F Ménissier (Inra, SGQA, F 78352 Jouy-en-Josas cedex, France) for his valuable help during the process of publication of this article.

\section{REFERENCES}

Anonymous (1978) Selection program for dairy and beef production through Artificial Insemination in Cuba. In: Breeding and Artificial Insemination, FAO/SIDA Seminar, 30 October, 1978, Habana, Cuba

Baptist Von R, Gravert HO (1973) Die Fruchtbarkeit der Tochter in der Bullen Selection. Zuchtung 45, 339-411

Berger PJ, Shanks RD, Freeman AE, Laben RC (1981) Genetic aspects of milk yield and reproductive performance. J Dairy Sci 64, 114-126

Blanchard PJ, Everett RW, Searle SR (1983) Estimation of genetic trends and correlations for Jersey cattle. J Dairy Sci 66, 1947-1954

Caleyo M (1989) Un programa para estimaciones BLUP del valor genético de los sementales. VIII Jornada CIMA, November 1989, Cotorro, La Habana, Cuba

Calo LL, McDowell RE, Van Vleck LD, Miller PD (1973) Genetic aspects of beef production among Holstein-Friesians pedigree selected for milk production. J Anim Sci $37,676-682$

Caral J, Iglesias C, Martínez G, Solano R (1984). Influencia del número de parto en el período intercelo y distribución anual de partos en ganado Holstein. In: Reproduction des ruminants en zone tropicale ( $\mathrm{P}$ Chemineau, D Gauthier, J Thimonier, eds), 8-10 juin 1983, Pointe-à-Pitre (FWI). Les Colloques de L'INRA no 20, 491 (abstract), Inra Versailles

De los Reyes A (1985) Causas de variación no genéticas que afectan la producción del ganado Holstein y estimación de factores de ajuste por edad. Tesis Doctor en Ciencias, La Habana, Cuba

Dempfle L, Hagger C, Schneeberger M (1983) On the estimation of genetic parameters via variance components. Genet Sel Evol 15, 425-444

Distl O (1982) Selection for fertility traits. Proc 2nd World Cong Genet Appl Liv Prod, 4-8 October 1982, Madrid, Spain, Vol 7, 580-585, Editorial Garsi, Madrid

Foote RH (1978) Reproductive performance and problems in New York dairy herds. Search Agric Anim Sci 8, 18

Guerra D, Cordoví J, de los Reyes A (1987) Parámetros genéticos de las primeras tres lactancias en vacas Holstein. II Jornada ACPA, mayo 29-30, 1987, Ciudad de Habana, Cuba

Hansen LB, Freeman AE, Berger PJ (1983) Association of heifer fertility with cow fertility and yield in dairy cattle. Dairy Sci 66, 306-314

Heiman MM (1982) Breeding Israelí Holstein. Holstein Herdbook, Summary of 1982 milk and butterfat production

Ingraham RM, Gillette DD, Wagner WD (1974) Relationship of temperature and humidity to conception rate of Holstein cows in subtropical climate. J Dairy Sci 57, 476-481

Jansen J (1986) Studies of fertility in dairy cattle on analysis of AI data. Wageningen Lands, PhD Thesis, The Netherlands

Janson L (1980) Studies on fertility traits in Swedish dairy cattle. Swedish Univ Agric Sci, Genetics Dept, report 45

Kennedy BW (1981) Variance component estimation and prediction of breeding values. Can J Genet Cytol 23, 565-578 
Kruif A de (1975) An investigation of the parameters which determine the fertility of a cattle population and some factors which influence these parameters. Tijdschr Dierg $100,1089-1098$

Lin CY, McAllister AJ (1984) Monte Carlo comparison of four methods for estimation of genetic parameters in the univariate case. J Dairy Sci 67, 2389-2398

Maijala K (1987) Genetic control of reproduction and lactation in ruminants. J Anim Breed Genet 104, 53-63

Menendez Buxadera A (1988) Importancia de la interacción genotipo-ambiente en la evaluación de sementales lecheros. Boletin Reseña, CIMA 6

Menendez Buxadera A (1993) Variacion genetica del comportamiento reproductivo en el vacuno: revision blibiographica. Rev Cubana Reprod Animal 19, 3-53

Menendez Buxadera A, Guerra D (1981) Relación entre el valor genético de sementales Holstein evaluados en Cuba, Canadá y México. Proc ALPA 16, 161

Menendez Buxadera A, Pérez B, Valle E, Rodríguez N, Herrera R, Varela O (1983) Crecimiento y desarrollo de la hembra Holstein en Cuba. IV Reun ACPA 1983, 69-89

Menendez Buxadera A, de los Reyes A, Guerra D, Cordoví J (1989). Genetic variability of milk production from Holstein cows according to the level of milk yield of the herd. Cub J Agric Sci 23, 9-15

Monty de Jr (1984) Early embryo death in cattle during thermal stress. In: Reproduction des ruminants en zone tropicale ( $\mathrm{P}$ Chemineau, D Gauthier, J Thimonier, eds), 8-10 juin 1983, Pointe-à-Pitre (FWI). Les Colloques de L'Inra no 20, 285-298, Inra Versailles

Patterson HD, Thompson R (1971) Recovery of interblock information when block sizes are unequal. Biometrika 58, 545-554

Prada N (1984) Programa nacional de mejoramiento genético vacuno. Rev ACPA 3, 20-26

Raheja KL, Burnside EB, Schaeffer LR (1989) Heifers fertility and its relationship with cow fertility and production traits in Holstein dairy cattle. J Dairy Sci 72, 2625-2629

Roman Ponce H (1992) Reproducción y manejo reproductivo de los bovinos productores de leche y carne en el tropico. In: Avances en la produccion de leche y carne en el Tropico Americano (Fernández-Boca, ed), Santiago de Chile, 1992, § IV 131-168, FAO

Ron M, Bar Anan R, Wiggans G (1984) Factors affecting conception rate of Israeli Holstein cattle. J Dairy Sci 67, 854-860

Strandberg E, Danell B (1988) Genetic and phenotypic parameters for production and days open period in the first three lactations of Swedish dairy cattle. Proc VI World Cong Anim Prod, Genetic section, June 27-July 1, 1988, Helsinki

Thatcher WW (1974) Effects of season, climate and temperature on reproduction and lactation. J Dairy Sci 5, 360-368

Thatcher WW, Badinga L, Collier RJ, Mead MM, Wilcox CJ (1984) Thermal stress effects on the bovine conceptus: early and late pregnancy. In: Reproduction des ruminants en zone tropicale (P Chemineau, D Gauthier, J Thimonier, eds), 8-10 juin 1983, Pointe-à-Pitre (FWI). Les Colloques de L'INRA no 20, 265-284, Inra Versailles

Van Raden PM, Freeman AE, Berger PJ (1987) Relationship among production and reproduction in nulliparous and first lactation Holstein cattle. 82th Meet ADSA, June 21-24, 1987, Columbia

Wazdauskas FC, Whittier WD, Vinson WE, Pearson RE (1986) Evaluation of reproductive efficiency of dairy cattle with emphasis on timing of breeding. J Dairy Sci 69, 290-297

Weller JJ (1989) Genetic analysis of fertility traits in Israeli dairy cattle. J Dairy Sci 72, 2644-2650. 